\title{
Thin-Capitalization Rules and Company Responses Experience from German Legislation
}

\author{
ALFONS J. WEICHENRIEDER \\ HELEN WINDISCHBAUER
}

CESIFo Working PAPER NO. 2456

CAtegory 1: Public FinANCE

NOVEMBER 2008

\footnotetext{
An electronic version of the paper may be downloaded

- from the SSRN website: www.SSRN.com

- from the RePEc website:

- from the CESifo website:

www.RePEc.org

www.CESifo-group.org/wp
} 


\title{
Thin-Capitalization Rules and Company Responses Experience from German Legislation
}

\begin{abstract}
By granting intracompany loans to their foreign affiliates, multinational firms may reduce their tax liability abroad. Many countries have legislated thin-capitalization rules (TCRs) that limit the allowable levels of intracompany loans or restrict interest deductibility if certain thresholds are crossed. This paper empirically analyzes the effect of the German TCR on corporate policy. We find that tightening the regulations in 2001 had some limiting effect on leverage. Foreign affiliates reacted by reducing intracompany loans and increasing equity, with no significant evidence of reduced real investment. A possible reason for the limited impact of the TCR was that multinational firms had the option to work around the regulation by using holding company structures. Indeed, holding companies have been used to shift huge amounts of intracompany loans onto the books of German affiliates. At the same time, however, only part of these observed reorganizations seem to have been a reaction to TCR.
\end{abstract}

JEL Code: H25, G38.

Keywords: multinational firm, debt, thin capitalization, financial structure.

\author{
Alfons J. Weichenrieder \\ Johann Wolfgang Goethe University \\ Faculty of Economics and Business \\ Administration \\ 60054 Frankfurt (Main) \\ Germany \\ a.weichenrieder@em.uni-frankfurt.de
}

\author{
Helen Windischbauer \\ Johann Wolfgang Goethe University \\ Faculty of Economics and Business \\ Administration \\ 60054 Frankfurt (Main) \\ Germany
}

This version: 29 September 2008

We are indebted to Dietmar Scholz and Jürgen Lüdicke for most helpful discussions and hints, and to Beatrix Stejskal-Passler and Nadine Riedel for important annotations. The hospitality of the research center of the Deutsche Bundesbank is gratefully acknowledged. The paper is part of a research project on capital market effects of the German tax reform 2001 funded by the Deutsche Forschungsgemeinschaft. 


\section{Introduction}

There is growing empirical evidence that multinational firms adapt their financial policies in a tax-efficient way. Studies on the financial structure of U.S. outbound investment (Foley, Desai, and Hines 2004, Altshuler and Grubert 2003) as well as German outbound investment (Mintz and Weichenrieder 2005) suggest that an increase in the host country tax rate by 10 percentage points on average increases the leverage of manufacturing firms by some $2-4$ percentage points. Countries with high tax rates therefore seem to attract a considerable amount of tax-deductible interest cost. To a considerable extent the debt that multinationals shift into high-tax countries takes the form of cross-border intracompany loans. Germany, which during most of the 1990s had the highest corporate tax rate among OECD countries, is an obvious example. Ramb and Weichenrieder (2005) point out that at the end of the 1990s this type of finance on average accounted for some 20 percent of the balance-sheet total of German manufacturing corporations that were held by a foreign direct investor.

Governments may react in several ways to curb tax-efficient financing schemes that come at a tax revenue cost. One method taken by some home countries of multinationals (Japan, the U.S., and Italy) is to use interest allocation rules. ${ }^{1}$ Under an interest allocation rule, the interest deduction is allocated according to a pro rata share. That is, for tax purposes, there may apply a compulsory shift of interest deductions from the parent firm to the foreign affiliates.

In this paper we will consider thin-capitalization rules that are applied by host countries of multinational firms. A thin-capitalization rule (TCR) typically restricts the tax deductibility of interest if the amount of loans granted by the investor or a closely related party is deemed excessive. In France, for example, an interest payment by a foreign-owned corporation to its investor may be qualified as a dividend, if the loans provided by this

\footnotetext{
${ }^{1}$ See Altshuler and Mintz (1995).
} 
investor exceed $150 \%$ of her equity share. Similar TCRs with various ratios are used, for example, in Denmark, Belgium, and the Netherlands. ${ }^{2}$ In recent years, thin-capitalization rules have attracted additional political attention because of their possible interference with European law. The European Court of Justice (ECJ) disallowed application of a former German thin-capitalization rule to companies operating in Germany if the loan is given by an investor located in an EU member country. The ECJ held that the rule selectively discriminated against EU investors.

So far there have been few empirical studies on the economic effects of TCRs. ${ }^{3} \mathrm{~A}$ recent exception is Buettner et al. (2007), who argue that German investment abroad tends to be more tax-sensitive if the host country employs a TCR. Overesch and Wamser (2006) provide some evidence that tightening of TCR rules reduces the fraction of intracompany loans in German FDI financing. The present paper is an effort to further improve our knowledge of the working of TCRs in practice. In this paper we will highlight the empirical reactions of foreign companies to the German TCR legislation. Besides the immediate question whether the introduction or tightening of the TCR has had the desired effects on the amount of intracompany loans, a second question is how firms have accommodated. For example, a multinational that faces restrictions in financing its German affiliate by intracompany loans could react by using more equity or more third-party debt, or it could reduce investment along with the amount of intracompany loans.

Yet another possibility is that multinationals succeed in working around legal restrictions. Particular weak spots in the legislation may allow this. For example, the German TCR, which was introduced in 1994, featured a special preference for holding companies. It provided a safe-haven debt-to-equity ratio of 3:1 for all nonbank corporations, but provided a more lenient 9:1 safe haven for holding companies. That is, an interest payment from a German holding company to its foreign investor was safe from being

\footnotetext{
${ }^{2}$ See the decision on the Lankhorst-Hohorst GmbH case (C-324-00) of 12 December 2002.

${ }^{3}$ For recent theoretical papers, which analyze thin-capitalization rules as measures of international tax competition, see Haufler and Runkel (2008) or Fuest and Hemmelgarn (2005).
} 
qualified as a dividend as long as ratio of the investor's loans to his or her equity in the firm was smaller than 900 percent. Under the German 1994 TCR rule this may have invited the use of domestic holding corporations to work around the more stringent 3:1 rule. ${ }^{4}$ A main purpose of this paper is therefore not only to look at the financing reaction of foreign affiliates in Germany, but also to consider empirically, by drawing on information provided by the Deutsche Bundesbank database MiDi, the extent to which firms took advantage of this loophole.

The reminder of the paper is organized as follows. In Section 2 we will give a description of the German TCR and describe its evolution over time. Section 3 introduces the MiDi data that are used for the present analysis, and Section 4 then empirically examines corporate reactions to the 2001 change in the German TCR. Section 5 investigates to what extent holding companies have been used as vehicles to work around the German TCR. Section 6 concludes.

\section{The Evolution of the German TCR}

In Germany, an explicit TCR was legislated in 1993 and became effective in January 1994. Before that date no explicit rules existed. ${ }^{5}$ The newly introduced $\S 8 \mathrm{a}$ of the corporate tax code $(\mathrm{KStG})$ allowed the authorities to qualify an interest payment as a deemed dividend if the loans granted by an investor exceeded three times his or her share in total corporate equity as measured at the end of the last fiscal year. In such a case the deemed dividend then reduced the tax deductibility of interest for German corporate taxes. An exception applied if the firm could convincingly argue that the same loan would have also been granted by a nonaffiliated third party or if the loan was only given temporarily. Effectively, the regulation

\footnotetext{
${ }^{4}$ In a recent study, Weichenrieder and Mintz (2007) highlight possible additional roles of holding companies for avoiding taxation in an international setting. Empirically, another important role is the minimization of withholding taxes.

${ }^{5}$ An attempt to curb thin capitalization by using a bylaw of the finance ministry was overturned by the courts. See Weichenrieder (1995, p. 177) for an account of the history of the German TCR.
} 
created a safe haven if the intracompany-debt-to-equity ratio of three or less was complied with, while higher levels of thin capitalization created the risk of nondeductible interest payments. The German TCR is only applicable if the investor's share in the corporation is at least 25 percent (including shares held indirectly via affiliated entities). It also fails to be binding for unincorporated businesses like branches of foreign multinationals and partnerships. Since the rule only applied to investors who could not claim an imputation tax credit for dividends to reduce German income taxes, the TCR was mainly relevant for foreign owners of German corporations who are not subject to German income tax.

As mentioned above, the 1994 TCR gave a preference to holding companies that could receive a loan from their owners up to nine times their equity stake in the firm (safe haven of 9:1). ${ }^{6}$ To be considered a holding company under the regulation, a corporation must either restrict itself to the provision of financial services to affiliated companies or hold shares in other corporations amounting to $75 \%$ of total assets or more.

A first revision of $\S 8 \mathrm{a} \mathrm{KStG}$ became effective in January 2001. From 2001 the safe haven for nonholding companies was reduced to $1.5: 1$, i.e., an interest payment could be deemed a dividend if the loans granted by an investor exceeded her share of the corporate equity by 50 percent. $^{7}$ While this further limited the amount of intracompany loans provided by a foreign parent to a German affiliate, a preference for holding companies continued to apply. The safe haven for these companies was set at a ratio of $3: 1$.

A second revision of the TCR was triggered by a ruling of the ECJ. In its decision of 12 December 2002 it held that the German rule discriminated against EU investors. This triggered a revision of the German TCR, which became effective in January 2004. The rules continue to allow deeming interest payments to affiliated parties to be dividends if the loan granted by an investor exceeds 150 percent of the investor's share of corporate equity. ${ }^{8}$

\footnotetext{
${ }^{6}$ A special provision is available for banks.

${ }^{7}$ For loans with a variable interest rate a smaller safe haven of $0.5: 1$ applied.

${ }^{8}$ Corporations that can argue that a third party would have granted the loan at a comparable interest rate may exceed the ratio under the old and new rules.
} 
However, they now apply to foreign and domestic investors alike. In addition, the preferential safe haven for holding companies was lifted. As a measure to protect small and medium-sized domestic firms with loans granted by their shareholders, interest is not deemed a dividend if the interest paid to the investor falls short of $€ 250,000$. Because of lacking data for the post-2004 era, this paper does not attempt to give empirical evidence on the effects of this last revision, but is mainly concerned with the introduction and the 2001 revision. Finally, it should be mentioned that Germany has recently enacted a further change in its approach towards thin capitalization. From the year 2008, the thin-capitalization rule has been replaced by an earnings-stripping rule. ${ }^{9}$ Yet, the experience with previous legislation can give potentially important lessons for the future and for other countries.

\section{German FDI Statistics}

To evaluate the impact of German TCR legislation we make use of the German FDI database MiDi of the Deutsche Bundesbank. By law, affiliates of foreign investors have to report a reduced balance sheet to the Deutsche Bundesbank if the total assets of the direct investment meet mild size requirements. For wholly owned affiliates of foreign investors, this was DM 500,000 from 1989 to 1992, DM 1,000,000 from 1993 to 2001, and €3,000,000 from 2002. In the case where a foreign-owned company holds yet another German company, information has also to be provided on this dependent company, allowing a look at ownership chains of foreign-owned firms in Germany.

Among other things, the database gives information on equity, third-party debt, loans received from affiliated firms inside and outside Germany, and total assets of foreign-owned affiliates in Germany. This information on financial structure makes the data a very good basis for our empirical investigation. ${ }^{10}$

\footnotetext{
${ }^{9}$ For details see Bundesministerium der Finanzen (2007).

${ }^{10}$ Other studies that have used the German FDI database MiDi to identify tax effects on foreign-owned firms include Becker, Fuest, and Hemmelgarn (2006) and Ramb and Weichenrieder (2005).
} 
The firm-level data from 1996 to 2004 has a panel structure that allows tracking of firms across years. Unfortunately, this panel structure is missing for the years 1989 to 1995 , and during this period firms cannot be traced over time. This implies that some effects of the German legislation can only be measured in a limited way. If, for example, the introduction of the TCR in 1994 has given incentives to use new holding companies to take advantage of their preferential treatment, then this behavior can only be detected since 1996. Similarly, changes in the financial structure from the 1994 introduction of the TCR cannot be traced on a firm level during the period 1994-1996. Our evaluation of the empirical effects will therefore rest largely on the analysis of the 2001 reform of the rules.

\section{TCR and the effect on high-leveraged firms}

A first empirical question is whether the introduction in 1994 and the further tightening in 2001 of the German TCR formed a binding restriction on firms with pronounced thin capitalization and triggered a reduction in the relative prominence of intracompany loans. Figure 1 provides some descriptive evidence for nonfinancial incorporated affiliates by depicting the ratio $R$ of an investor's loans (plus the loans granted by other foreign-affiliated firms) to the 'investor's share of total equity in German-incorporated affiliates over time. ${ }^{11}$ More precisely, the figure plots this ratio for a firm in the $25^{\text {th }}$ percentile, for one in the $75^{\text {th }}$ percentile, and for the median firm. The firms in the $75^{\text {th }}$ percentile show very high intracompany loans provided by the foreign investor relative to his share in total equity.

Throughout the period 1989-2002 all nonfinancial corporations in the $75^{\text {th }}$ percentile received loans from foreign investors or foreign-affiliated companies that amounted to more than $200 \%$ of the foreign investor's equity. Simple eyeball econometrics would suggest that

\footnotetext{
${ }^{11}$ While the German TCR calls for using the lagged values of equity when calculating the safe-haven ratio, we have to rely on the current equity for pre-1996 periods, as firms can be followed over time only from 1996 onwards. For consistency reasons current equity is also used in Figure 1 for later years. Because of a special exemption for banks and differences in balance sheets, we excluded financial firms.
} 
the introduction of the TCR in 1994 and its tightening in 2001 were accompanied by a decrease in intracompany debt. While the pre-1994 value was around $400 \%$ for a firm in the $75^{\text {th }}$ percentile, it came down to some $300 \%$ after the introduction of the TCR and stayed in this range for a couple of years, only to experience an additional decrease after the tightening of the TCR in 2001.

Of course, the picture drawn by Figure 1 may be deceptive. It is conceivable that even without the introduction and tightening of the TCR, a moderating time trend or other reasons for a reduced use of intracompany loans were present. For example, the cut in the German headline corporate tax from $40 \%$ to $25 \%$ in 2001 may have made intracompany loans less attractive (see Ramb and Weichenrieder 2005).

Figure 2 is constructed similarly to Figure 1, but restricts attention to foreign-owned branches (including partnerships), which are not subject to the German TCR. The graph shows that thin capitalization is not restricted to corporations, but can also be found for branches. Throughout the period 1989-2004, more than 20 percent of the unincorporated foreign-owned firms had a ratio $R$ above 2 : loans from foreign affiliated firms amounted to at least 200 percent of the foreign investor's equity. While branches have not been affected by the introduction of the TCR in 1994 and its tightening in 2001, they also showed a decline in the use of intracompany loans over time. Conversely, during the years following the tightening of the rules in 2001, branches showed a smaller reduction in $R$ than did corporations. Like corporations, branches experienced a decrease in the federal German profit tax rate from 40 to 25 percent in 2001 . 
Figure 1: Foreign loans over equity, corporations

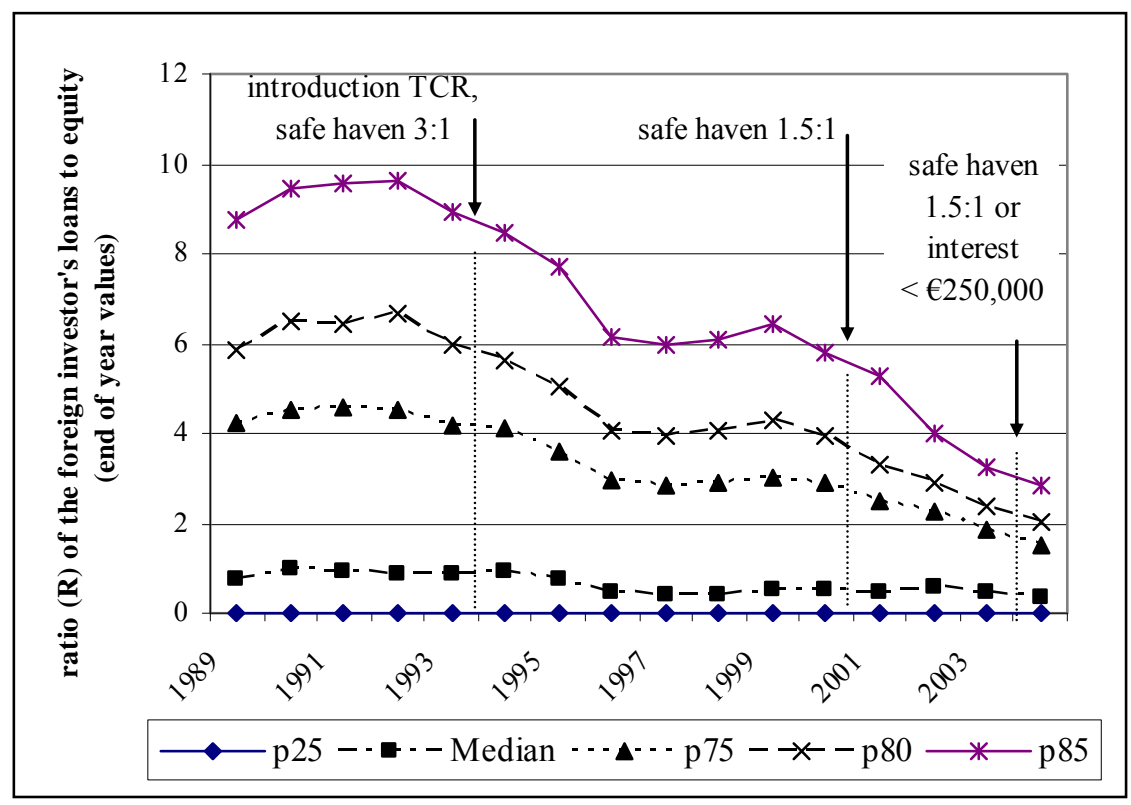

Annotation: $\mathrm{R}$ is defined as a foreign investor's loans to a German affiliate, divided by his share in the affiliate's total capital (= paid up capital + capital reserves + surplus reserves + profit or loss carry forwards). The upper curve (p75) denotes the value of $R$ for a foreign firm in the $75^{\text {th }}$ percentile; the middle curve, the median firm; and the lowest curve (p25), the value for the $25^{\text {th }}$ percentile. The figure represents nonfinancial incorporated affiliates the immediate (co-)owner of which is a foreign investor. Holding companies have also been excluded.

Figure 2: Foreign loans over equity, branches

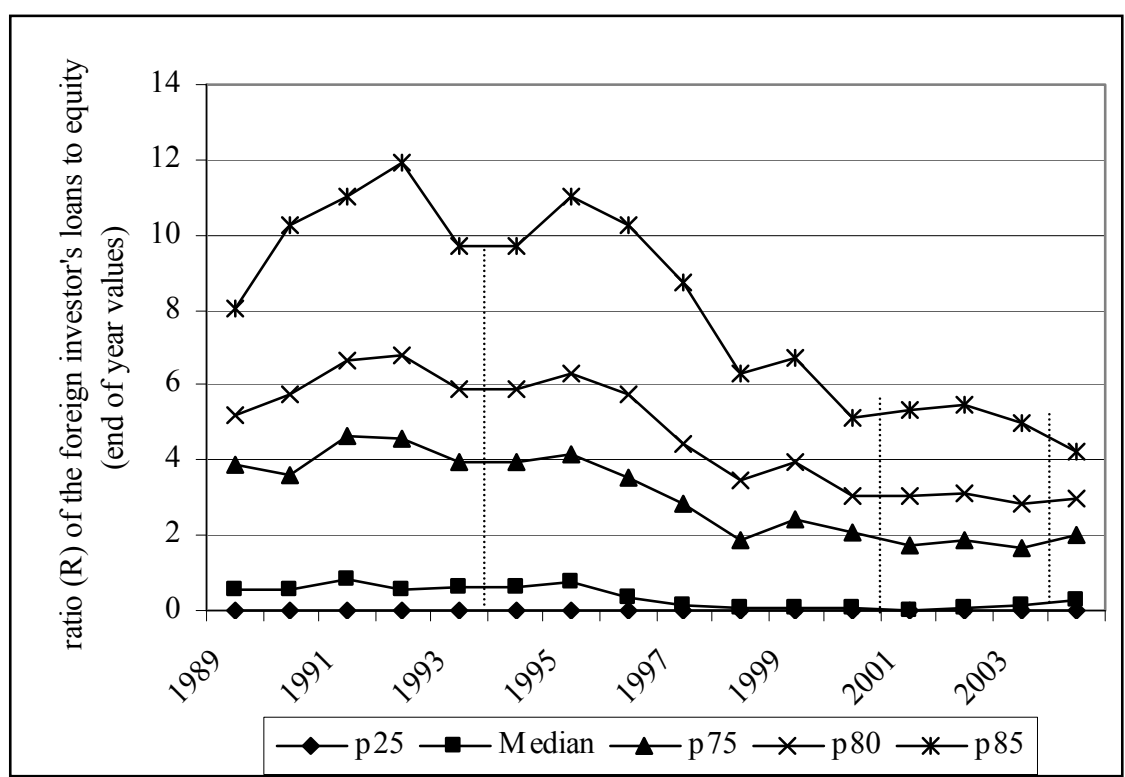

Annotation: The figure represents nonfinancial unincorporated affiliates the immediate (co-)owner of which is a foreign investor. For definitions see Figure 1. 
In the next step we want to investigate econometrically the specific reactions that the tightening of the TCR rules had on foreign-owned firms in Germany, using micro data. A problem that persists even with micro data at hand is that any decrease in the relative use of intracompany loans after the introduction may be attributable to a common time trend - the (uniform) reduction of the income taxes on branches and incorporated affiliates, or other common shocks - rather than to the tightening of the TCR. In other words, we are in need of a control group that was not subject to the tightening of the TCR. While foreign-owned corporations were potentially affected by the 2001 reform of the TCR, the regulations do not apply to foreign partnerships and foreign-owned branches located in Germany. We therefore consider these latter types of businesses as a potential control group, which we will in the following call simply "branches". ${ }^{12}$

An important firm characteristic that we are interested in is the definition of intrafirm debt as it is applied by the TCR. We therefore define the variable IRAT as the ratio of intrafirm debt, which a company has received from foreign-affiliated firms, to the total equity of the firm in the preceding year. The lag in the denominator of the ratio is motivated by the fact that such a lag is present in the relevant definition of the safe haven in the German tax code. Since in the following we will concentrate on years for which the data set has a panel structure, we can eschew the (somewhat simpler) ratio $R$, which was used in Figure 1 and Figure 2, and replace it with IRAT. In the year 2000, a company may either have had an IRAT of more or less than 1.5. If the reform of the TCR was affecting firm financial policy, then we should expect that firms that in 2000 had already complied with the 2001 safe haven had a smaller incentive to reduce their IRAT than did firms that found themselves in a situation beyond the future safe haven. More importantly, within the group of firms that in 2000 showed an IRAT of more than 1.5, corporations should have had a

\footnotetext{
${ }^{12}$ A conceivable alternative control group consists of firms with less than 25 percent foreign ownership. We did not pursue this alternative for two reasons. First, the number of foreign-owned firms having a foreign ownership between 10 and 25 percent is relatively small. Second, unlike branches, these firms have a much different financial structure with few loans from foreign-affiliated firms.
} 
larger incentive to reduce their IRAT than branches, as the TCR and its revision were not applicable to the latter group. In particular, corporations should have felt a larger incentive to reduce the ratio than branches. The strategy to empirically identify the effects of the regulation therefore is to look at whether corporations that in the year 2000 started with an IRAT of more than 150 percent showed a subsequent reduction in the amount for intracompany loans that was larger than the reduction for the control groups. ${ }^{13}$

Of course, to be a suitable control group, branches should have similar financial structures to corporations. As Figure 1 and Figure 2 show, this was roughly the case in 2000, the year preceding the reform.

We start the empirical analysis by defining several variables. CORP takes on the value 1 if the firm under consideration is incorporated (and potentially affected by the TCR). It is zero otherwise. Conversely, the dummy BRANCH takes on the value 1 if CORP $=0$. The variable RATIO is created as a dummy that equals zero if a firm in the year 2000 had an IRAT below or equal to 1.5 , and that equals one otherwise. Finally, we employ a time dummy D01_02 that marks the years 2001 and 2002 in which the tightened regulation was effective, but takes on the value zero in 2000 .

The variables used in our regression are built by interacting these dummies:

$$
\begin{gathered}
\text { CORP_HIGH_01_02 }=\mathrm{CORP} \cdot \mathrm{RATIO} \cdot \mathrm{D} 01 \_02, \\
\text { CORP_LOW_01_02 }=\mathrm{CORP} \cdot(1-\mathrm{RATIO}) \cdot \mathrm{D} 01 \_02, \\
\text { BRANCH_HIGH_01_02 }=(1-\mathrm{CORP}) \cdot \mathrm{RATIO} \cdot \mathrm{D} 01 \_02, \\
\text { BRANCH_LOW_01_02 }=(1-\mathrm{CORP}) \cdot(1-\mathrm{RATIO}) \cdot \mathrm{D} 01 \_02 .
\end{gathered}
$$

\footnotetext{
${ }^{13}$ We decided not to use data on 2003 , because such data could have been contaminated by the expectation of the 2004 reform.
} 
With the help of these variables we can form a baseline regression that uses IRAT as the endogenous variable:

$$
\begin{aligned}
\operatorname{IRAT}_{\mathrm{it}}=t_{\mathrm{t}} & +f_{\mathrm{i}}+b_{1} \cdot \mathrm{CORP} \_\mathrm{HIGH} \_01 \_02_{\mathrm{it}}+b_{2} \cdot \mathrm{BRANCH} \text { HIGH_01_02 it } \\
& +b_{3} \cdot \mathrm{BRANCH} \_ \text {LOW_01_02 } 2_{\mathrm{it}}+b_{4} \cdot \mathrm{SALES}_{\mathrm{it}}+u_{\mathrm{it}} .
\end{aligned}
$$

Here $t$ is a year fixed effect, $f$ is a firm fixed effect, and SALES is the yearly turnover of an observed firm. $u$ is the error term. By construction, $b_{1}, b_{2}$, and $b_{3}$ measure how the endogenous variable developed in 2001 and 2002 compared to the starting year 2000. More precisely, because we included time fixed effects, the coefficients capture the differential effect with respect to the excluded base group CORP_LOW, i.e., the group of corporations that started out with IRAT $<1.5$ in 2000 . First, we expect that the coefficient $b_{1}$ will be significantly negative, since corporations that started out with $\operatorname{IRAT}_{2000}>1.5$ should have felt a larger pressure to adapt their financial structure than corporations that were already complying. While such a negative coefficient would be consistent with an influence of the TCR on financial policy, it could also result from a general tendency of high-leveraged firms to return to lower leverage. Therefore, we will also test whether $b_{1}$ is significantly different from the coefficient $b_{2}$ that takes up the reactions of thinly capitalized branches.

To perform the regression we introduced several restrictions on the sample of selected firms. First, while the MiDi database contains firms that are indirectly owned by a foreign investor via a German intermediate firm, we concentrate on firms that are directly held by a foreign investor with an ownership share of at least $25 \%$. Only this type of firms was affected by the pre-2004 TCR. Second, we drop firms that have more than one foreign investor. The reason is that the TCR requires calculating the ratio IRAT on an investor level, which from our data is impossible if there is more than one foreign investor. Third, to calculate the ratio IRAT for the year 2000 we need 1999 information on equity. This additionally reduces the sample. Fourth, we exclude observations with negative values of lagged equity, as in these cases it is not possible to calculate a sensible value for IRAT. Fifth, we excluded holding companies, banks, and other financial firms that received a 
different treatment under the TCR and/or possess a very different financial structure. Finally, we require the firms in our sample to have three consecutive observations. ${ }^{14}$ This leaves us with a working sample of 1699 corporations and branches observed over the period 20002002.

Table 1 gives an overview of the firms in our four different baskets. Using the borderline of IRAT $=1.5$, we have 109 branches with low levels of thin capitalization $($ IRAT $\leq 1.5)$, and 34 branches with a high level (IRAT $>1.5$ ). Corporations are somewhat more likely to fall in the high basket than branches: we have 576 high-leveraged corporations and 980 for which IRAT $\leq 1.5$.

Within the group of branches (corporations) that in 2000 had a ratio of 1.5 or less, the average was $0.286(0.437)$. Branches and incorporated affiliates are roughly similar when we look at the subgroups of firms that in 2000 had IRAT $>1.5$ : for incorporated firms IRAT then averaged 525 percent, compared to 431 percent for branches.

Interestingly, the average size of the firms (as measured by turnover) in the four baskets hardly depends on incorporation. Indeed, the average sales in the low and high baskets are slightly higher for branches.

Table 2 reports the result for the empirical model in equation (5), while Table 3 contains the relevant descriptive statistics of the sample. First, consider the column in Table 2 that uses IRAT as the dependent variable. As explained above, we grouped firms into four baskets. We included dummies for three groups and chose low-leveraged corporations as the base case for which no dummy applies. The significant negative coefficient of the variable CORP_HIGH_01_02 therefore indicates that corporations that in 2000 started out with high intracompany loans (IRAT $>1.5$ ) significantly reduced their thin

\footnotetext{
${ }^{14}$ During our period of interest (2000-2002) there was a change in the reporting requirement that induced the dropout of a large number of small firms with less than $€ 3$ million balance sheet total. The requirement of three consecutive observations makes sure that for our sample the number of observations per firm is not correlated with firm size. Since the endogenous variable is a ratio with equity in the denominator, equity losses sometimes produce very extreme values in the endogenous variable. We therefore excluded 5 percent of the remaining firms on the basis that their value of IRAT in one of the three years exceeded 20.9. We also excluded a limited number of firms that changed from an incorporated to an unincorporated status during our period of interest.
} 
capitalization in the following two years, in contrast with corporations that started out with a value of IRAT below 1.5.

While this result is indicative, one may object that corporations in the high-leveraged subsample had simply more opportunity to reduce this ratio. To infer whether the tightening of the thin-cap rules was effective, it is therefore necessary to compare the corporations that started with IRAT $>1.5$ with those unincorporated firms that also started out with a high level of thin capitalization. If there is a different effect on corporations from that on unincorporated firms that were not affected by the tightening of the regulation, then we should expect the coefficient $b_{1}$ to be significantly different (smaller) from the estimated coefficient $b_{2}$. Indeed, this is the case, and the linear restriction $b_{1}=b_{2}$ is rejected at the 5percent level. On average, high-leveraged corporations reduced IRAT by 120 percentage points more than high-leveraged branches.

The next five columns report how other balance sheet items have reacted to the tightening of the TCR. One way to accommodate a reduction of intracompany loans could be to reduce investment. The results in the second column give no evidence of such a reaction. The coefficient for high-leveraged corporations does not differ from that of lowleveraged corporations, nor does it differ from the one for high-leveraged unincorporated firms. The hypothesis $b_{1}=b_{2}$ cannot be rejected at usual significance levels. The third regression shows that, if anything, corporations that tended to be affected by the tightening of the TCR increased their financial assets more than other corporations. But the test $b_{1}=b_{2}$ is only rejected at the 11-percent level. Another possible reaction of corporations to accommodate to the tightened TCR is to increase equity. In comparison with low-leveraged corporations, the increase in equity for high-leveraged corporations indeed is highly significant. When the change is compared with the change for unincorporated firms with high leverage, however, the difference in differences is not significant. The fifth regression in Table 2 shows the relative change in intracompany loans. The estimated coefficient of -1.034 for $b_{1}$ implies that, compared with low-leveraged levered corporations, high- 
leveraged corporations reduced their average amount of intracompany loans by 103 percent. ${ }^{15}$ The comparison with high-leveraged unincorporated businesses yields no significant results, that is, the hypothesis $b_{1}=b_{2}$ cannot be refuted.

The estimated coefficients for log SALES turn out to be insignificant in columns 1 through 4 of Table 2, but at least weakly significant and positive in columns 5 and 6 . This suggests that firms that experience an increase in sales tend to prefer an increase in intracompany loans and third-party debt over an increase in equity.

Table 1: Comparison of groups (2000)

\begin{tabular}{lcccc}
\hline \hline Variable & BRANCH_LOW & BRANCH_HIGH & CORP_LOW & CORP_HIGH \\
\hline IRAT (avg./median) & $0.286 \mid 0.041$ & $4.317 \mid 2.949$ & $0.437 \mid 0.258$ & $5.255 \mid 3.556$ \\
SALES (avg./median) & $58486 \mid 12000$ & $77205 \mid 22500$ & $56953 \mid 18000$ & $67545 \mid 21000$ \\
Firms & 109 & 34 & 980 & 576 \\
\hline \hline
\end{tabular}

Annotations: The first figure denotes the mean value of a variable in the respective basket, the second denotes the median. Sales are measured in thousands of euros.

To examine the robustness of our results and to gain additional insights into the working of the thin-capitalization rules, we also tested a finer grouping of firms. For that purpose we divided all firms for which in the year 2000 IRAT was larger than 1.5 into three subgroups. HIGH1 (HIGH2, HIGH3) indicates the lowest (middle, highest) leveraged subgroup with IRAT $>1.5$. The dividing lines between these subgroups were drawn such that each of the three groups had the same number of firms. This produced the following thresholds based on year 2000 information. For subgroup HIGH1, $1.5<$ IRAT $<2.61$. For subgroup HIGH2 (HIGH3), $2.61<$ IRAT < 5 (IRAT > 5). While this additional grouping may allow identifying more exactly what types of firms did react, the split-up produces rather small groups of unincorporated affiliates against which the development of corporations can be compared. While 188, 189, and 199 corporations fall in the groups HIGH1, HIGH2, and HIGH3, the corresponding group sizes are 13, 12, and 9 for branches.

\footnotetext{
${ }^{15}$ This of course must imply that the control group of firms on average increased their intracompany loans, allowing for a difference of more than 100 percent.
} 
Table 2: Differential effects on thin capitalization of incorporated firms

\begin{tabular}{lrrrrrr}
\hline \hline & & $\begin{array}{r}\text { Log of fixed } \\
\text { assets and } \\
\text { intangibles }\end{array}$ & $\begin{array}{r}\text { Log of } \\
\text { financial } \\
\text { assets }\end{array}$ & $\begin{array}{r}\text { Log of } \\
\text { equity }\end{array}$ & $\begin{array}{r}\text { Log of } \\
\text { intracompany } \\
\text { loans }\end{array}$ & $\begin{array}{r}\text { Log of third- } \\
\text { party debt }\end{array}$ \\
\cline { 2 - 7 }$b_{1}$ : CORP_HIGH_01_02 & -1.624 & 0.062 & 0.084 & 0.138 & -1.034 & 0.142 \\
& {$[0.00]^{* * *}$} & {$[0.42]$} & {$[0.57]$} & {$[0.00]^{* * *}$} & {$[0.00]^{* * *}$} & {$[0.11]$} \\
$b_{2}$ : BRANCH_HIGH_01_02 & -0.417 & -0.230 & -0.826 & 0.022 & -1.161 & -0.260 \\
& {$[0.43]$} & {$[0.45]$} & {$[0.14]$} & {$[0.78]$} & {$[0.01]^{* *}$} & {$[0.53]$} \\
$b_{3}$ : BRANCH_LOW_01_02 & 0.061 & -0.128 & 0.136 & -0.077 & 0.335 & -0.072 \\
& {$[0.61]$} & {$[0.44]$} & {$[0.57]$} & {$[0.35]$} & {$[0.43]$} & {$[0.50]$} \\
$b_{4}$ : Log of SALES & $-0,009$ & 0.037 & -0.008 & 0.007 & 0.072 & 0.066 \\
& {$[0.77]$} & {$[0.11]$} & {$[0.82]$} & {$[0.23]$} & {$[0.08]^{*}$} & {$[0.02]^{* *}$} \\
\hline TEST $b_{1}=b_{2}$ & -1.207 & 0.361 & 0.910 & 0.11 & 0.127 & 0.402 \\
& {$[0.03]^{* *}$} & {$[0.36]$} & {$[0.10]$} & {$[0.14]$} & {$[0.78]$} & {$[0.34]$} \\
\hline Observations & 5097 & 5097 & 5097 & 5097 & 5097 & 5097 \\
Firms & 1699 & 1699 & 1699 & 1699 & 1699 & 1699 \\
Adj. R ${ }^{2}$ & 0.77 & 0.92 & 0.93 & 0.92 & 0.83 & 0.82 \\
\hline \hline
\end{tabular}

Annotations: $* * *$ significant at $1 \%$ level, **significant at $5 \%$ level, *significant at $10 \%$ level. P-values in brackets are based on robust t-statistics (corrected for correlations within firm cells and heteroscedasticity). All regressions contain year dummies and a full set of firm dummies, the coefficients of which are not reported. To avoid losing firms with zero reported sales, we added 1 one euro before taking logs. The same applies to the other logged variables.

Table 3: Sample statistics

\begin{tabular}{lrrrrr}
\hline \hline Variable & Observations & Firms & Average & Median & Std.deviation \\
\hline IRAT & 5097 & 1699 & 1.945 & 0.704 & 3.255 \\
$\begin{array}{l}\text { Log of SALES } \\
\begin{array}{l}\text { Log of third-party } \\
\text { debt }\end{array}\end{array}$ & 5097 & 1699 & 9.436 & 9.852 & 3.387 \\
$\begin{array}{l}\text { Log of fixed assets } \\
\text { and intangibles }\end{array}$ & 5097 & 1699 & 7.709 & 7.938 & 2.379 \\
$\begin{array}{l}\text { Log of financial } \\
\text { assets }\end{array}$ & 5097 & 1699 & 6.782 & 7.314 & 3.066 \\
$\begin{array}{l}\text { Log of equity } \\
\text { Log of intracompany }\end{array}$ & 5097 & 1699 & -0.399 & 0.001 & 6.787 \\
loans & 5097 & 1699 & 8.015 & 7.954 & 7.092 \\
\hline \hline
\end{tabular}

As in the regressions of Table 2, corporations that start out with a low level of IRAT in 2000 act as the baseline group against which other groups of firms are compared. The numbers of firms and total observations are also kept unchanged. The estimates for the variables CORP_HIGH1_01_02, CORP_HIGH2_01_02, and CORP_HIGH3_01_02 confirm that highly thin-capitalized corporations significantly reduced IRAT after the year 2000 as compared to less leveraged corporations. The comparison between corporations and 
branches in different thin-capitalization groups is captured by the three tests in the lower part of the table. The results show that only in the extremely leveraged comparison groups did corporations have a significantly stronger reduction of IRAT than branches. While this seems to suggest limited evidence for the impact of the 2001 reform on corporations, one should keep in mind the rather small group sizes.

As in Table 2, the results of Table 4 show now evidence that corporations reacted to the tightened TCR by disinvesting (column 2) or reducing financial assets (column 3). At the same time, the results in column (4) suggest that the affected corporations increased their equity to comply with the tightened rules. The significance of the reduction in intracompany loans depends on the comparison group. The reduction is always significant for highleveraged corporations if the comparison is with low-leveraged corporations. If compared with branches having similar leverage, then the policy change is only significant for group HIGH2. 
Table 4: Differential effects in different thin-cap classes

\begin{tabular}{|c|c|c|c|c|c|c|}
\hline & IRAT & $\begin{array}{r}\text { Log of fixed } \\
\text { and } \\
\text { intangibles } \\
\text { assets }\end{array}$ & $\begin{array}{r}\text { Log of } \\
\text { financial } \\
\text { assets }\end{array}$ & $\begin{array}{l}\text { Log of } \\
\text { equity }\end{array}$ & $\begin{array}{r}\text { Log of } \\
\text { intracomp } \\
\text { any loans }\end{array}$ & $\begin{array}{l}\text { Log of third- } \\
\text { party debt }\end{array}$ \\
\hline$a_{1}:$ CORP_HIGH1_01_02 & $\begin{array}{r}-0.280 \\
{[0.05]^{* *}}\end{array}$ & $\begin{array}{l}0.077 \\
{[0.51]}\end{array}$ & $\begin{array}{c}0.226 \\
{[0.31]}\end{array}$ & $\begin{array}{r}0.088 \\
{[0.04]^{* *}}\end{array}$ & $\begin{array}{r}-1.220 \\
{[0.00]^{* * *}}\end{array}$ & $\begin{array}{c}0.091 \\
{[0.54]}\end{array}$ \\
\hline$a_{2}:$ CORP_HIGH2_01_02 & $\begin{array}{r}-0.623 \\
{[0.00]^{* * *}}\end{array}$ & $\begin{array}{c}0.033 \\
{[0.81]}\end{array}$ & $\begin{array}{r}-0.069 \\
{[0.76]}\end{array}$ & $\begin{array}{r}0.116 \\
{[0.01]^{* *}}\end{array}$ & $\begin{array}{r}-1.031 \\
{[0.00]^{* * *}}\end{array}$ & $\begin{array}{c}0.076 \\
{[0.62]}\end{array}$ \\
\hline$a_{3}:$ CORP_HIGH3_01_02 & $\begin{array}{r}-3.846 \\
{[0.00]^{* * *}}\end{array}$ & $\begin{array}{c}0.074 \\
{[0.40]}\end{array}$ & $\begin{array}{c}0.094 \\
{[0.63]}\end{array}$ & $\begin{array}{r}0.206 \\
{[0.00]^{* * *}}\end{array}$ & $\begin{array}{r}-0.860 \\
{[0.00]^{* * *}}\end{array}$ & $\begin{array}{r}0.252 \\
{[0.03]^{* *}}\end{array}$ \\
\hline$a_{4}:$ BRANCH_LOW_01_02 & $\begin{array}{r}-0.062 \\
{[0.61]}\end{array}$ & $\begin{array}{r}-0.128 \\
{[0.44]}\end{array}$ & $\begin{array}{r}0.136 \\
{[0.57]}\end{array}$ & $\begin{array}{r}-0.077 \\
{[0.35]}\end{array}$ & $\begin{array}{c}0.335 \\
{[0.43]}\end{array}$ & $\begin{array}{r}-0.072 \\
{[0.50]}\end{array}$ \\
\hline$a_{5}:$ BRANCH_HIGH1_01_02 & $\begin{array}{l}-0.674 \\
{[0.06]^{*}}\end{array}$ & $\begin{array}{r}-0.921 \\
{[0.35]}\end{array}$ & $\begin{array}{r}-1.208 \\
{[0.30]}\end{array}$ & $\begin{array}{l}0.110 \\
{[0.21]}\end{array}$ & $\begin{array}{r}-1.324 \\
{[0.00]^{* * *}}\end{array}$ & $\begin{array}{r}-0.902 \\
{[0.38]}\end{array}$ \\
\hline$a_{6}:$ BRANCH_HIGH2_01_02 & $\begin{array}{c}0.220 \\
{[0.82]}\end{array}$ & $\begin{array}{l}0.112 \\
{[0.22]}\end{array}$ & $\begin{array}{r}-1.275 \\
{[0.05]^{* *}}\end{array}$ & $\begin{array}{r}-0.061 \\
{[0.71]}\end{array}$ & $\begin{array}{c}-0.296 \\
{[0.09]^{*}}\end{array}$ & $\begin{array}{c}0.071 \\
{[0.42]}\end{array}$ \\
\hline$a_{7}:$ BRANCH_HIGH3_01_02 & $\begin{array}{r}-0.912 \\
{[0.51]}\end{array}$ & $\begin{array}{c}0.046 \\
{[0.78]}\end{array}$ & $\begin{array}{c}0.324 \\
{[0.65]}\end{array}$ & $\begin{array}{c}0.006 \\
{[0.96]}\end{array}$ & $\begin{array}{r}-2.080 \\
{[0.18]}\end{array}$ & $\begin{array}{c}0.224 \\
{[0.51]}\end{array}$ \\
\hline$a_{8}: \log$ of SALES & $\begin{array}{c}0.015 \\
{[0.58]}\end{array}$ & $\begin{array}{r}0.036 \\
{[0.10]^{*}}\end{array}$ & $\begin{array}{r}-0.008 \\
{[0.82]}\end{array}$ & $\begin{array}{c}0.007 \\
{[0.21]}\end{array}$ & $\begin{array}{r}0.072 \\
{[0.09]^{*}}\end{array}$ & $\begin{array}{r}0.066 \\
{[0.02]^{* *}}\end{array}$ \\
\hline TEST $a_{1}=a_{5}$ & $\begin{array}{c}0.393 \\
{[0.30]}\end{array}$ & $\begin{array}{c}0.998 \\
{[0.32]}\end{array}$ & $\begin{array}{c}1.434 \\
{[0.23]}\end{array}$ & $\begin{array}{r}-0.022 \\
{[0.82]}\end{array}$ & $\begin{array}{r}0.103 \\
{[0.77]}\end{array}$ & $\begin{array}{c}0.993 \\
{[0.34]}\end{array}$ \\
\hline $\operatorname{TEST} a_{2}=a_{6}$ & $\begin{array}{r}-0.843 \\
{[0.40]}\end{array}$ & $\begin{array}{r}-0.079 \\
{[0.60]}\end{array}$ & $\begin{array}{r}1.206 \\
{[0.07]^{*}}\end{array}$ & $\begin{array}{c}0.178 \\
{[0.30]}\end{array}$ & $\begin{array}{r}-0.735 \\
{[0.00]^{* * *}}\end{array}$ & $\begin{array}{c}0.005 \\
{[0.97]}\end{array}$ \\
\hline $\operatorname{TEST} a_{3}=a_{7}$ & $\begin{array}{r}-2.934 \\
{[0.04]^{* *}}\end{array}$ & $\begin{array}{r}0.028 \\
{[0.86]}\end{array}$ & $\begin{array}{r}-0.229 \\
{[0.76]} \\
\end{array}$ & $\begin{array}{r}0.200 \\
{[0.10]^{*}}\end{array}$ & $\begin{array}{r}1.220 \\
{[0.43]}\end{array}$ & $\begin{array}{r}0.028 \\
{[0.94]}\end{array}$ \\
\hline Observations & 5097 & 5097 & 5097 & 5097 & 5097 & 5097 \\
\hline Firms & 1699 & 1699 & 1699 & 1699 & 1699 & 1699 \\
\hline Adj. $R^{2}$ & 0.79 & 0.93 & 0.93 & 0.92 & 0.83 & 0.82 \\
\hline
\end{tabular}

Annotations: $* * *$ significant at $1 \%$ level, $* *$ significant at $5 \%$ level, $*$ significant at $10 \%$ level. P-values in brackets are based on robust t-statistics (corrected for correlations within firm cells). To avoid losing firms with zero reported sales, we added 1 euro before taking logs. The same applies to the other logged variables.

By and large, our estimation results indicate that the tightened TCR was successful in reducing thin capitalization. ${ }^{16}$ At the same time, we find no evidence that firms that were most likely to be affected by the new rule reduced investment. ${ }^{17}$ Instead, the results suggest

\footnotetext{
${ }^{16}$ This is also confirmed by a recent paper by Overesch and Wamser (2006) that does not consider the exact channels through which the firms reacted.

${ }^{17} \mathrm{We}$ also checked whether firms that, because of their initial value of IRAT, were particularly affected by the TCR tightening had a smaller survival probability in subsequent years, but found no such evidence.
} 
that corporations with high levels of thin capitalization increased their equity and tended to reduce intracompany loans.

\section{The creation of ownership chains}

As discussed in the previous section, a foreign firm that faces the need to adjust its financial structure because of a thin-capitalization rule may increase its equity base, increase the use of third-party debt, or reduce the amount of intracompany loans along with total assets.

In the German case, also a less straightforward route was conceivable. Given that holding companies enjoyed a preferential safe haven under the 1994 TCR, foreign investors may have found it attractive to use an ownership chain to circumvent the implications of the TCR for nonholding companies. Figure 3 illustrates. Under a direct ownership structure (case A), the allowable debt-to-equity ratio was 3:1 for fiscal years 1994 to 2000. Under an alternative indirect structure (case B), the parent establishes a holding company and endows it with a debt-to-equity ratio as high as 9:1. These funds can be used by the holding company to buy the preexisting affiliate from the parent without triggering a net inflow of funds into Germany. ${ }^{18}$ The larger the purchase price, the larger the total debt and equity that can be allocated to the holding company. Since the holding company is a German legal entity, it does not fall under the 1994 TCR and may endow the affiliate with debt. But even if it holds only equity of the affiliate, the total allowable intracompany debt that could be channeled to Germany is larger than in the direct case.

Unlike in the direct case A, the dividends paid by the affiliates do not directly accrue to the parent, but take a route via a holding company. In a last step, to ensure that the interest paid on the parent debt is tax-deductible from the profits earned by the affiliate, the two

\footnotetext{
${ }^{18}$ It should be mentioned that the holding company, to qualify for the preferential safe haven, had to hold at least one additional company, the size of which was irrelevant, however.
} 
German affiliates have to enter into a profit transfer agreement to assure tax consolidation between the holding company and the affiliate, which allows interest paid by the affiliate to be used to reduce profits transferred to the holding company.

Figure 3: Direct versus indirect ownership structure

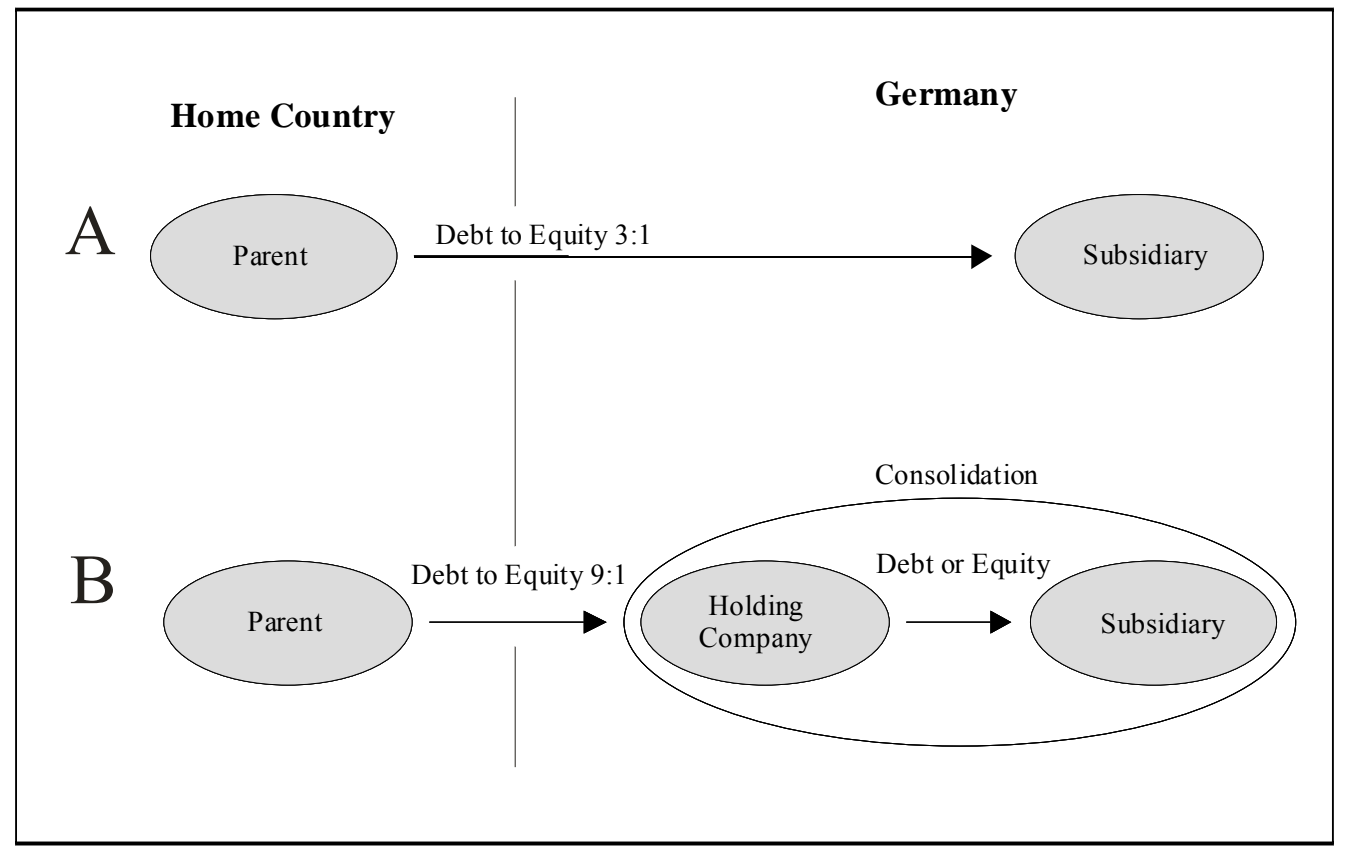

After 2000, a change from a direct to an indirect ownership structure still allowed larger amounts of intracompany debt for German affiliates, but, as laid out above, while the safe haven for normal corporations was set to $1.5: 1$, the safe haven for holding companies was only lowered to $3: 1$. The scheme laid out above was well known to tax-law practitioners (see Krebs 1998), and it is an empirical question to what extent it indeed was used to escape the German TCR. Our principal question in this section therefore is the possible extent to which foreign-owned firms have changed their internal structure from a direct one to an indirect one as illustrated by Figure 3?

Again, our investigation is impeded by the fact that the database MiDi lacks a panel structure for years prior to 1996, which makes it impossible to track foreign affiliates over time for the period 1993-1996, so changes in the ownership structure can only be detected 
after 1996. A change in ownership structure from direct to indirect may have been motivated by the TCR if the following conditions hold:

- The corporation that is used to form the ownership chain must be a holding company, as only those could benefit from the preferential safe haven.

- The ownership fraction that the holding company acquires in the affiliate must be at least $50 \%$, the minimum to establish a profit transfer agreement that is accepted for tax purposes.

- The dependent affiliate must be outside the banking industry, as this industry is not affected by the German TCR.

Table 5: Affiliates with change from direct to indirect ownership ${ }^{19}$

\begin{tabular}{|c|c|c|c|c|c|c|}
\hline & (1) & (2) & (3) & (4) & (5) & (6) \\
\hline Year & $\begin{array}{l}\text { Changes from } \\
\text { direct to indirect } \\
\text { (constant parent) }\end{array}$ & $\begin{array}{l}\text { Thereof: } \\
\text { pre- } \\
\text { existing } \\
\text { holding } \\
\text { company }\end{array}$ & $\begin{array}{l}\text { Changes from } \\
\text { direct to indirect } \\
\text { (constant country } \\
\text { of parent) }\end{array}$ & $\begin{array}{l}\text { Thereof: } \\
\text { pre- } \\
\text { existing } \\
\text { holding } \\
\text { company }\end{array}$ & $\begin{array}{l}\text { Changes from } \\
\text { direct to indirect } \\
\text { (changing } \\
\text { country of } \\
\text { parent) }\end{array}$ & $\begin{array}{l}\text { Thereof: } \\
\text { pre- } \\
\text { existing } \\
\text { holding } \\
\text { company }\end{array}$ \\
\hline 1997 & 11 & $<4$ & 23 & 19 & 14 & 8 \\
\hline 1998 & 18 & 5 & 26 & 13 & 19 & 13 \\
\hline 1999 & 16 & 5 & 36 & 17 & 18 & 12 \\
\hline 2000 & 13 & $<4$ & 26 & 18 & 19 & 10 \\
\hline 2001 & 14 & 5 & 28 & 16 & 17 & 6 \\
\hline 2002 & 12 & $<4$ & 23 & 11 & 15 & 7 \\
\hline 2003 & 10 & 5 & 20 & 10 & 11 & 6 \\
\hline Total & 94 & 28 & 182 & 104 & 113 & 62 \\
\hline
\end{tabular}

Annotation: The table reports the number of affiliates that are reported as indirectly held via a German intermediate holding company, but were owned directly by a foreign investor in the preceding reported year. To be included, the dependent affiliate must not be in the banking sector, and the holding company in the ownership chain in the current year must own at least $50 \%$ of the equity. As in the preceding section, we excluded affiliates with more than one foreign investor.

Based on the above criteria, we found a total of 389 foreign-owned affiliates that initially were held directly by a foreign investor and were transformed into an indirect participation via a German holding company at some point between 1996 and the end of 2003. In 94

\footnotetext{
${ }^{19}$ In 48 cases a single holding company took over two or more previously directly held affiliates in the same year.
} 
cases, the change from direct to indirect ownership via a German holding company left the identity of the foreign parent unchanged (Table 5, column 1). But some of the restructurings were accompanied by other changes in ownership: in 182 cases the inclusion of the German holding company was accompanied by a change in the identity of the foreign parent firm, but the new parent resided in the same country (Table 5, column 3 ). ${ }^{20}$ In these cases, the restructuring in Germany may have been going along with a restructuring of the corporate group in the parent country. A German affiliate that used to be held via a certain corporation abroad may have been moved to a different corporation within the same company group. Hence, the ultimate foreign group that owns the German affiliate could have stayed the same. Conversely, the previous parent may have sold the German affiliate to a new investor who then preferred a German ownership chain rather than direct ownership. In this second case, tax considerations are less likely to be the decisive reason for the change to indirect ownership. For example, the new owner at the time of purchase of the German affiliate may have already owned a German holding company and for governance reasons may have decided to transfer the ownership to it. Indeed, while only $30 \%$ of the 94 affiliates in column 1 were transferred to a preexisting holding company for which data in the database is available years prior to acquisition, ownership for $57 \%$ of the 182 companies of column 2 was transferred to a preexisting German holding company. So we decided to report this case separately.

Besides the cases reported in columns 1 and 3, column 5 also reports cases in which both the parent and the country of the parent have changed. In these cases, $55 \%$ of the affiliates were transferred to preexisting holding companies, $45 \%$ of the affiliates were taken over by holding companies that in the previous years were not included in the database.

\footnotetext{
${ }^{20}$ The MiDi database does not give information on characteristics of the foreign parent, but it reports an identification number for the parent and the country of residency.
} 
Table 6: Developments in balance sheet items (bn. $€$ )

\begin{tabular}{|c|c|c|c|c|c|c|c|c|c|c|c|c|c|c|c|c|c|c|c|}
\hline & \multirow{3}{*}{ Years } & \multicolumn{6}{|c|}{ Ultimate parent unchanged } & \multicolumn{6}{|c|}{ Parent stays in same country } & \multicolumn{6}{|c|}{ Country of parent changes } \\
\hline & & \multicolumn{2}{|c|}{ Affiliates } & \multicolumn{4}{|c|}{ Holding comp. } & \multicolumn{3}{|c|}{ Affiliates } & \multicolumn{3}{|c|}{ Holding comp. } & \multicolumn{2}{|c|}{ Affiliates } & \multicolumn{4}{|c|}{ Holding comp. } \\
\hline & & $\begin{array}{l}0 \\
0 \\
\stackrel{0}{0} \\
\stackrel{0}{\Xi}\end{array}$ & 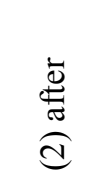 & 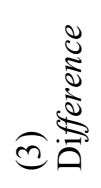 & 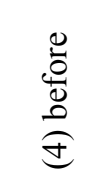 & $\frac{\dot{\Phi}}{\stackrel{E}{E}}$ & 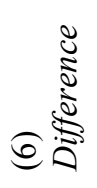 & $\begin{array}{l}0 \\
0 \\
0 \\
0 \\
0 \\
E\end{array}$ & 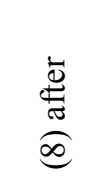 & 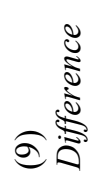 & $\begin{array}{l}0 \\
\stackrel{0}{0} \\
\stackrel{0}{0} \\
\stackrel{0}{0}\end{array}$ & 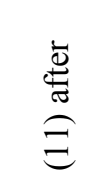 & ปิ & $\begin{array}{l}0 \\
\stackrel{0}{0} \\
\stackrel{0}{0} \\
\stackrel{\approx}{=}\end{array}$ & 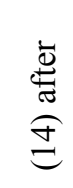 & 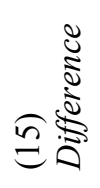 & 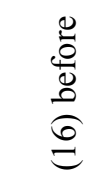 & 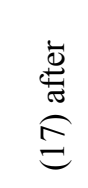 & 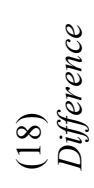 \\
\hline \multirow[t]{2}{*}{ Equity } & $97-00$ & 2.1 & 2.0 & -0.2 & 1.4 & 6.1 & 4.7 & 2.5 & 3.1 & 0.6 & 4.9 & 13.9 & 8.9 & 1.2 & 1.4 & 0.2 & 8.4 & 16.3 & 7.9 \\
\hline & $01-03$ & 0.6 & 0.5 & -0.1 & 1.7 & 5.0 & 3.3 & 1.4 & 1.6 & 0.2 & 5.2 & 10.1 & 5.0 & 0.8 & 1.1 & 0.4 & 3.4 & 7.4 & 4.0 \\
\hline \multirow[t]{2}{*}{ Debt } & $97-00$ & 4.0 & 4.1 & 0.1 & 1.5 & 8.3 & 6.9 & 3.8 & 4.0 & 0.2 & 6.7 & 21.5 & 14.9 & 2.5 & 2.4 & -0.1 & 8.0 & 16.1 & 8.0 \\
\hline & $01-03$ & 1.2 & 0.9 & -0.3 & 5.5 & 6.4 & 1.0 & 2.7 & 3.2 & 0.5 & 7.1 & 17.9 & 10.7 & 1.6 & 2.8 & 1.2 & 5.1 & 8.2 & 3.1 \\
\hline Loans from affiliated & $97-00$ & 0.9 & 1.4 & 0.5 & 1.4 & 8.1 & 6.8 & 1.8 & 1.6 & -0.2 & 6.0 & 20.6 & 14.6 & 1.1 & 1.3 & 0.1 & 6.5 & 13.4 & 6.9 \\
\hline companies & $01-03$ & 0.5 & 0.3 & -0.2 & 4.3 & 5.3 & 1.0 & 1.7 & 1.9 & 0.2 & 6.6 & 15.9 & 9.3 & 1.1 & 2.0 & 0.9 & 4.9 & 7.5 & 2.6 \\
\hline Loans from affiliated & $97-00$ & 0.7 & 0.6 & -0.2 & 0.8 & 6.8 & 6.0 & 1.4 & 0.6 & -0.8 & 3.7 & 17.4 & 13.6 & 0.9 & 0.5 & -0.4 & 4.2 & 10.2 & 6.0 \\
\hline companies outside Germany & $01-03$ & 0.4 & 0.1 & -0.3 & 3.8 & 4.3 & 0.5 & 1.0 & 0.8 & -0.2 & 3.6 & 13.6 & 10.0 & 0.7 & 0.3 & -0.4 & 3.6 & 4.9 & 1.3 \\
\hline \multirow[t]{2}{*}{ Other liabilities } & $97-00$ & 4.4 & 5.2 & 0.9 & 0.1 & 0.2 & 0.2 & 7.5 & 7.2 & -0.2 & 0.3 & 0.7 & 0.4 & 0.3 & 0.4 & 0.1 & 3.3 & 3.1 & -0.2 \\
\hline & $01-03$ & 0.2 & 0.3 & 0.1 & 0.2 & 0.3 & 0.2 & 0.9 & 1.0 & 0.1 & 0.2 & 0.3 & 0.1 & 0.4 & 1.2 & 0.8 & 0.1 & 0.0 & 0.0 \\
\hline \multirow[t]{2}{*}{ Total assets } & $97-00$ & 10.7 & 12.0 & 1.3 & 3.0 & 15.2 & 12.2 & 14.8 & 16.6 & 1.8 & 9.5 & 32.9 & 23.4 & 4.3 & 4.7 & 0.4 & 22.1 & 34.6 & 12.5 \\
\hline & $01-03$ & 2.2 & 1.8 & -0.4 & 7.6 & 12.5 & 4.9 & 5.0 & 5.7 & 0.7 & 11.6 & 26.9 & 15.4 & 2.9 & 4.8 & 2.0 & 7.2 & 14.5 & 7.3 \\
\hline \multirow[t]{2}{*}{ Fixed assets and intangibles } & $97-00$ & 2.5 & 3.0 & 0.5 & 0.0 & 0.1 & 0.0 & 1.6 & 1.7 & 0.1 & 0.3 & 0.3 & 0.0 & 0.5 & 0.5 & 0.0 & 0.1 & 0.0 & -0.1 \\
\hline & $01-03$ & 0.5 & 0.4 & -0.1 & 0.1 & 0.1 & 0.0 & 0.9 & 1.6 & 0.7 & 0.1 & 0.0 & -0.1 & 0.9 & 0.9 & 0.0 & 0.0 & 0.1 & 0.0 \\
\hline \multirow[t]{2}{*}{ Financial assets } & $97-00$ & 2.8 & 3.0 & 0.3 & 2.5 & 12.9 & 10.4 & 7.8 & 7.2 & -0.6 & 6.4 & 27.4 & 21.0 & 1.8 & 1.9 & 0.1 & 16.2 & 26.1 & 9.9 \\
\hline & $01-03$ & 0.7 & 0.5 & -0.2 & 6.3 & 10.5 & 4.1 & 1.3 & 0.8 & -0.6 & 8.6 & 22.7 & 14.0 & 0.8 & 1.7 & 0.9 & 5.4 & 10.9 & 5.5 \\
\hline Shares in affiliated & $97-00$ & 1.7 & 1.5 & -0.2 & 2.5 & 12.6 & 10.1 & 4.7 & 3.9 & -0.8 & 5.9 & 26.5 & 20.6 & 1.7 & 1.8 & 0.1 & 15.8 & 25.5 & 9.6 \\
\hline companies & $01-03$ & 0.5 & 0.2 & -0.3 & 6.2 & 10.2 & 3.9 & 1.1 & 0.7 & -0.5 & 7.7 & 21.9 & 14.2 & 0.8 & 1.3 & 0.5 & 5.2 & 10.4 & 5.2 \\
\hline Loans to affiliated & $97-00$ & 0.0 & 0.1 & 0.1 & 0.0 & 0.3 & 0.3 & 0.1 & 0.2 & 0.1 & 0.3 & 0.7 & 0.4 & 0.0 & 0.0 & 0.0 & 0.4 & 0.4 & 0.1 \\
\hline companies & $01-03$ & 0.1 & 0.0 & -0.1 & 0.1 & 0.3 & 0.2 & 0.1 & 0.1 & -0.1 & 0.9 & 0.7 & -0.1 & 0.0 & 0.3 & 0.3 & 0.0 & 0.4 & 0.4 \\
\hline
\end{tabular}


A first question is whether the changes in ownership structure that are described by Table 5 have economic significance. The 94 affiliates that are reported in column 1 represented a balance sheet total of some $€ 13.8 \mathrm{bn}$. evaluated at the end of the year in which the respective changes in the ownership link occurred. The equivalent figure for the group of 182 affiliates in column 3 is $€ 22.3 \mathrm{bn}$., and the balance sheet total of the 113 affiliates in column 5 was $€ 9.5 \mathrm{bn}$. These figures compare to the balance sheet total of all directly held affiliates in our sample (with at least 50 percent foreign ownership, outside banking) of $€ 180 \mathrm{bn}$. in 1997, representing 6198 affiliates. The comparable figure for 2004 is $€ 415 \mathrm{bn}$., representing 3980 affiliates. $^{21}$ Clearly, the firms that experienced a change from direct ownership to indirect ownership via a German holding company were above average size, and the total assets involved are considerable, reflecting a moderate but nonmarginal fraction of total foreign-owned assets in Germany.

In a next step, we investigate to what extent the changes in the ownership links have triggered an increase in total debt within Germany and, concurrently, an increase of debt tax shelter. Table 6 collects the relevant data. Since the advantages of using a German holding company structure were lowered by the 2001 TCR reform, we split all restructurings between 1997 and 2003 into those that occurred until 2000 and those that occurred between 2000 and 2003. When we compare the year before and after the change of the ownership link and look at the total debt variable for the 94 firms with a constant ultimate parent, we find that the total volume of debt was roughly kept constant. For those firms restructured before 2001, columns 1 and 2 indicate that the aggregated value of total debt was $€ 4.0 \mathrm{bn}$. before and $€ 4.1 \mathrm{bn}$. in the year after the restructuring. Restructurings after 2000 , in total, have been associated with a reduction in debt. The fact that the restructurings did not significantly increase the debt levels of affiliates does not rule out a tax motivation for the change in the ownership link. Such a conclusion would overlook that the holding companies heavily increased their debt levels. For these, the aggregated values of total debt increased

\footnotetext{
${ }^{21}$ The reduction of the number of affiliates is due to a redefinition of the reporting requirements in 2002 .
} 
by $€ 6.9 \mathrm{bn}$. in $1997-2000$ and by $€ 1.0 \mathrm{bn}$ in $2001-2003$. These changes mainly reflect an aggregated increase in loans from affiliated companies outside Germany by €6.0bn. (€0.5bn.) in 1997-2000 (2001-2003). The total assets of the holding companies involved moved from $€ 3.0 \mathrm{bn}$. to $€ 15.2 \mathrm{bn}$. in the first time window and from $€ 7.6 \mathrm{bn}$. to $€ 12.5 \mathrm{bn}$. in the second (columns 4 and 5). ${ }^{22}$ The increase in total assets that was experienced by the holding companies in both time windows was somewhat larger than the total assets of the affiliates that were taken over. This may indicate either that the purchase price (paid to the foreign parent) was considerably larger than the equity of the acquired affiliate, or that the holding company bought other assets during the year of the ownership change. The database allows calculating the increase in financial assets of the holding companies that are associated with the year of the ownership change. The vast majority of the $€ 12.2 \mathrm{bn}(€ 4.9 \mathrm{bn}$.) in years $1997-$ 2000 (2001-2003) reflected an increase in shares in affiliated companies. Only a small portion of the increase came from investments in other financial assets. Hence, if the holding companies invested in other assets than the German affiliate, which was acquired from the parent, then the other financial investments were also in affiliated firms.

Overall, the data for the 94 cases in which a directly held affiliate has been transformed into an indirect participation implies that the transactions were suitable for reducing taxable income in Germany. On the one hand, the funds channeled to Germany are used by the holding companies to earn tax-exempt income from owning shares in affiliated companies. On the other hand, a large fraction of the funds provided by the foreign parent took the form of intracompany loans, the interest on which is tax-deductible in Germany and taxable abroad. The extent to which the ownership restructurings have pumped debt into Germany has changed over the years. While the holding companies involved have increased their borrowings from affiliated companies considerably when the holding company privilege was still generous (i.e., before 2001), the effect in later years has flattened off.

\footnotetext{
${ }^{22}$ For this calculation the debt and total assets of firms that did not appear in the data prior to the ownership change was set to zero. Since the reporting requirements are rather moderate, this should lead to only small errors.
} 
Next, consider the 182 cases in which the affiliate experienced a change from direct to indirect participation, but the ultimate parent changed even though the country of the ultimate investor stayed the same. Again, a comparison of the last year before the ownership change to the first balance sheet after the change shows that, also in this group of restructurings, most changes in leverage occurred at the level of the German holding companies, but hardly at the level of the ultimate German affiliate. Total assets of the 182 affiliates moved from $€ 14.8 \mathrm{bn}$. to $€ 16.6 \mathrm{bn}$. ( $€ 5.0$ to $€ 5.7 \mathrm{bn}$.), and their debt increased by $€ 0.2 \mathrm{bn}(€ 0.5 \mathrm{bn})$. At the same time, the shares in affiliated companies of the holding companies involved increased by $€ 20.6 \mathrm{bn}$. (€14.2bn.) for restructurings in the period $1997-$ 2000 (2001-2003). The takeover of the preexisting affiliates went along with a huge increase in debt levels at the holding company level. Total debt increased by $€ 14.9 \mathrm{bn}$. and $€ 10.7 \mathrm{bn}$. in the two time windows, and the lion's share involved intracompany loans.

Finally, consider the 128 cases of changes in the ownership chain that implied a change of the country of the foreign direct investor. Evaluated at the year after the ownership change, the total assets of the affiliates were $€ 4.7 \mathrm{bn}$. and $€ 4.8 \mathrm{bn}$. during the two time windows. Compared to these values, the increase in the shares of the holding companies was quite pronounced at $€ 9.6 \mathrm{bn}$. and $€ 5$.2bn. In the first (second) time window, the restructuring was associated with an increase of cross-border intracompany loans by $€ 6.0 \mathrm{bn} .(€ 1.3 \mathrm{bn}$.).

Taken together, the figures in Table 6 imply that the 389 cases of restructuring of ownership were accompanied by an increase of intracompany loans to German holding companies of $€ 37.4 \mathrm{bn}$., $68 \%$ of which occurred before the tightening of the TCR from 2001.

Since a large fraction of holding companies that served as vehicles to increase German intracompany loans are new establishments, this points to a potential problem of previous studies that tried to identify the effects of international tax differentials on leverage decisions. Often these studies employ fixed-effects panel estimations that cannot take up the 
effect of new firms. To the extent that changes of leverage are conducted by using new vehicles, within estimators that only capture the change occurring in existing affiliates may underestimate debt shifting activities.

The above calculations illustrate that ownership restructurings have been extensively used to increase the level of intracompany loans from abroad. A remaining issue is the extent to which the increase in intracompany loans would have been possible without the use of holding companies. Instead of using intermediate holding companies, a directly held affiliate could pay out accumulated earnings as a dividend and borrow back these funds from its foreign parent. The attractiveness of this policy option depends of course on whether the TCR are already binding, and this is likely if the intracompany loans are larger than the relevant save haven. Evidence is provided by considering equity and intracompany loans from abroad aggregated on a company group level for those foreign investments that have been restructured using a German intermediate holding company. For this purpose, we take the sum of all intracompany loans that a group of German affiliates owes to affiliated companies outside Germany and divide it by the total equity of all the affiliates that are directly held by the foreign parent. We do not include the equity of indirectly held affiliates, as this should already be reflected in the equity of the German intermediate firm. Groups of companies are identified by the same identification number of their foreign parent. All numbers are collected for the years after an ownership change.

The figures collected in Table 7 show that in many cases, the aggregated ratio of cross-border intracompany loans to parent equity (post restructuring) would have complied with the respective TCR even without making use of the holding company privilege. For example, the median ratio for all company groups before 2001 was 2.136 , when the German TCR still provided a safe haven of 3. Similarly, the median for 2001-2003 was 1.228, when 1.5 was allowed by TCR standards. This suggests that for some foreign-owned firms the ownership restructuring may have been the preferred way of increasing leverage in Germany for other reasons than working round the TCR. At the same time, for quite a number of 
cases, the overall ratio of intracompany loans to net equity was beyond the respective safe haven, and the intention to work around the TCR is a prime candidate for explaining the restructuring.

Table 7: Group financing ratios (total loans from affiliated firms outside Germany divided by equity of directly held firms)

\begin{tabular}{lllll}
\hline & Observations & $25^{\text {th }}$ percentile & Median & $75^{\text {th }}$ percentile \\
\hline All restructurings & & & & \\
$1997-2000$ & 239 & .331 & 2.136 & 5.063 \\
2001-2003 & 150 & .238 & 1.228 & 2.745 \\
Same parent only & & & & \\
1997-2000 & 58 & .986 & 2.454 & 5.613 \\
2001-2003 & 36 & .219 & 0.899 & 2.784 \\
$\begin{array}{l}\text { Parent country unchanged, parent } \\
\text { changed }\end{array}$ & & & \\
1997-2000 & 111 & .316 & 2.695 & \\
2001-2003 & 71 & .316 & 1.738 & 2.869 \\
Parent country changed & & & & \\
1997-2000 & 70 & .178 & 1.058 & 3.877 \\
$2001-2003$ & 43 & .237 & 0.771 & 2.311 \\
\hline \hline
\end{tabular}

Table 8: Number of restructurings in thin-capitalized groups

\begin{tabular}{|c|c|c|c|c|c|c|}
\hline \multirow[b]{2}{*}{ Period } & \multicolumn{2}{|l|}{ (1) } & \multicolumn{2}{|l|}{ (3) } & \multicolumn{2}{|l|}{ (5) } \\
\hline & $\begin{array}{l}\text { Changes from } \\
\text { direct to indirect } \\
\text { (constant parent) }\end{array}$ & $\begin{array}{l}\text { Thereof: } \\
\text { above } \\
\text { TCR } \\
\text { threshold }\end{array}$ & $\begin{array}{l}\text { Changes from } \\
\text { direct to indirect } \\
\text { (constant country } \\
\text { of parent) }\end{array}$ & $\begin{array}{l}\text { Thereof: } \\
\text { above } \\
\text { TCR } \\
\text { threshold }\end{array}$ & $\begin{array}{l}\text { Changes from } \\
\text { direct to indirect } \\
\text { (changing } \\
\text { country of } \\
\text { parent) }\end{array}$ & $\begin{array}{l}\text { Thereof: } \\
\text { above } \\
\text { TCR } \\
\text { threshold }\end{array}$ \\
\hline $1997-2000$ & 58 & 24 & 111 & 65 & 70 & 27 \\
\hline $2001-2003$ & 36 & 11 & 71 & 48 & 43 & 19 \\
\hline Total & 94 & 35 & 182 & 113 & 113 & 46 \\
\hline
\end{tabular}

Table 8, which takes advantage of the same measure of leverage as Table 7 , reports on the exact number of restructurings that led to a thin capitalization above the safe haven level in the absence of a holding company and its privilege. Aggregated across all three types of restructurings, this has been the case for some $50 \%$ of the restructured affiliates. If we look at the relevant fraction of total debt increases due to higher holding company debt, we arrive at $58.1 \%$ for the $1997-2000$ period and at $77.2 \%$ for $2001-2003$. The available evidence suggests that debt increases were concentrated in groups of firms with pronounced 
thin capitalization (after restructuring). At the same time it suggests that in many cases the overall debt levels reached by the ownership change would have been possible without the intermediate holding company.

\section{Summary and Conclusions}

The paper has looked at the experience of the German TCR from various angles. The introduction in 1994 as well as the tightening of the rules in 2001 was followed by a visible reduction of thin capitalization among the foreign-owned affiliates with the largest fraction of cross-border intracompany borrowings as a fraction of equity. However, the role of the thin-capitalization rules needed careful econometric consideration, as the intracompany loans of branches, which did not fall under the TCR, experienced the same declining trend. The econometric analysis produced a significant effect of the TCR: the reduction of the ratio between loans from affiliated parties and foreign-owned equity was more pronounced for high-leveraged corporations then for unincorporated affiliates starting with a similar share of thin capitalization. In the German case, the TCR did not seem to produce a reduction in investment. While not or only weakly significant, our results suggest that affiliates reacted by using more equity and more third-party debt.

A second part of the paper has highlighted a loophole of the legislation that was due to a preference given to holding companies. For this reason, foreign multinationals could work around the German TCR by introducing a German intermediate holding company that used loans from affiliated companies abroad to buy a preexisting affiliate. Based on the MiDi data of the Deutsche Bundesbank, the paper shows that for the period 1997-2003 the use of holding company structures has been responsible for a total of more than $€ 37 \mathrm{bn}$. of new intracompany loans in the nonfinancial sector, which should have led to a sizable increase in tax-deductible interest in Germany and a loss in tax revenues. However, restructurings of this type were also observed in cases where the relative level of 
intracompany loans was low. Therefore, not all of the restructurings that have taken place can be interpreted as an effort to work around the TCR. Instead, for some of the cases the use of a leveraged intermediate holding company may have been considered an easier approach than an increase in the leverage of the operating affiliate. This is a potentially important message for empirical estimates of the elasticity of leverage with respect to tax rates. In many cases the empirical identification strategy has looked at the within variation of tax rates and leverage for a given set of affiliates. If multinationals rather react to tax differentials by setting up new affiliates, then the within variation may seriously underestimate the tax-rate elasticity of leverage. 


\section{Bibliography}

Altshuler, Rosanne and Jack Mintz (1995), "US interest-allocation rules: Effects and policy", International tax and public finance 2, 7-35.

Altshuler, Rosanne and Harry Grubert (2003), "Repatriation taxes, repatriation strategies and multinational financial policy", Journal of Public Economics 87(1), 73-107.

Becker, Johannes, Clemens Fuest, and Thomas Hemmelgarn (2006), Corporate tax reform and foreign direct investment in Germany: Evidence from firm-level data, CESifo Discussion Paper 1722.

Buettner, Thiess, Michael Overesch, Ulrich Schreiber, and Georg Wamser (2007), The impact of thin-capitalization rules on multinationals' financing and investment decisions, Ifo Discussion Paper.

Bundesministerium der Finanzen (2007), Monatsbericht März, 87-100.

Desai, M.A., C. Fritz Foley, and J.R. Hines (2004). "A Multinational Perspective on Capital Structure Choice and Internal Capital Markets", Journal of Finance 59, 2451-2488.

Fuest, Clemens and Thomas Hemmelgarn (2005), "Corporate tax policy, foreign firm ownership and thin capitalization", Regional Science and Urban Economics 35, 508-526.

Haufler, Andreas and Marco Runkel (2008), Firms' financial choices and thin capitalization rules under corporate tax competition, University of Munich, mimeo.

Krebs, Hans-Joachim (1998), "Steuerorientierte Umstrukturierung: Auswirkungen bei Fremdfinanzierung und Organschaft", Betriebsberater 53(43), 2183-2185.

Mintz, Jack and Alfons J. Weichenrieder (2005), Taxes and the financial structure of German outbound FDI, CESifo Working Paper 1612.

Overesch, Michael and Georg Wamser (2006), German inbound investment, corporate tax planning, and thin-capitalization rules: a difference-in-differences approach. ZEW Working Paper.

Ramb, Fred and Alfons J. Weichenrieder (2005), "Taxes and the financial structure of German inbound FDI", Review of World Economics (Weltwirtschaftliches Archiv), 141(4), 670-692.

Weichenrieder, Alfons J. (1995), Besteuerung und Direktinvestition. Tübingen. Mohr.

Weichenrieder, Alfons J. and Jack Mintz (2007), What determines the use of holding companies and ownership chains?, Discussion Paper, Oxford University Centre for Business Taxation, WP08/03. 


\section{CESifo Working Paper Series}

for full list see www.cesifo-group.org/wp

(address: Poschingerstr. 5, 81679 Munich, Germany, office@cesifo.de)

2397 Mohammad Reza Farzanegan, Illegal Trade in the Iranian Economy: Evidence from a Structural Model, September 2008

2398 Olivier Bos, Charity Auctions for the Happy Few, September 2008

2399 Robert S. Chirinko and Debdulal Mallick, The Marginal Product of Capital: A Persistent International Puzzle, September 2008

2400 Ben D'Exelle and Arno Riedl, Elite Capture, Political Voice and Exclusion from Aid: An Experimental Study, September 2008

2401 Torben M. Andersen and Joydeep Bhattacharya, On Myopia as Rationale for Social Security, September 2008

2402 Fabienne Llense, French CEO Compensations: What is the Cost of a Mandatory Upper Limit?, September 2008

2403 Valentina Bosetti, Carlo Carraro, Alessandra Sgobbi and Massimo Tavoni, Delayed Action and Uncertain Targets. How Much Will Climate Policy Cost?, September 2008

2404 Robert G. Chambers, Rolf Färe, Shawna Grosskopf and Michael Vardanyan, Generalized Quadratic Revenue Functions, September 2008

2405 Leonidas Enrique de la Rosa, Overconfidence in a Career-Concerns Setting, September 2008

2406 Marcus Drometer and Johannes Rincke, The Design of Political Institutions: Electoral Competition and the Choice of Ballot Access Restrictions in the United States, September 2008

2407 Markku Lanne and Helmut Lütkepohl, Stock Prices and Economic Fluctuations: A Markov Switching Structural Vector Autoregressive Analysis, September 2008

2408 Thomas L. Brewer, International Energy Technology Transfers for Climate Change Mitigations, September 2008

2409 Alexander Kemnitz, Native Welfare Losses from High Skilled Immigration, September 2008

2410 Xavier Vives, Strategic Supply Function Competition with Private Information, September 2008

2411 Fabio Padovano and Roberto Ricciuti, The Political Competition-Economic Performance Puzzle: Evidence from the OECD Countries and the Italian Regions, September 2008 
2412 Joan Costa-Font and Mireia Jofre-Bonet, Body Image and Food Disorders: Evidence from a Sample of European Women, September 2008

2413 Thorsten Upmann, Labour Unions - To Unite or to Separate?, October 2008

2414 Sascha O. Becker and Ludger Woessmann, Luther and the Girls: Religious Denomination and the Female Education Gap in $19^{\text {th }}$ Century Prussia, October 2008

2415 Florian Englmaier and Stephen Leider, Contractual and Organizational Structure with Reciprocal Agents, October 2008

2416 Vittorio Daniele and Ugo Marani, Organized Crime and Foreign Direct Investment: The Italian Case, October 2008

2417 Valentina Bosetti, Carlo Carraro, Alessandra Sgobbi and Massimo Tavoni, Modelling Economic Impacts of Alternative International Climate Policy Architectures. A Quantitative and Comparative Assessment of Architectures for Agreement, October 2008

2418 Paul De Grauwe, Animal Spirits and Monetary Policy, October 2008

2419 Guglielmo Maria Caporale, Christophe Rault, Robert Sova and Anamaria Sova, On the Bilateral Trade Effects of Free Trade Agreements between the EU-15 and the CEEC-4 Countries, October 2008

2420 Yin-Wong Cheung and Daniel Friedman, Speculative Attacks: A Laboratory Study in Continuous Time, October 2008

2421 Kamila Fialová and Ondřej Schneider, Labour Market Institutions and their Effect on Labour Market Performance in the New EU Member Countries, October 2008

2422 Alexander Ludwig and Michael Reiter, Sharing Demographic Risk - Who is Afraid of the Baby Bust?, October 2008

2423 Doina Maria Radulescu and Michael Stimmelmayr, The Welfare Loss from Differential Taxation of Sectors in Germany, October 2008

2424 Nikolaus Wolf, Was Germany ever United? Evidence from Intra- and International Trade 1885 - 1933, October 2008

2425 Bruno S. Frey, David A. Savage and Benno Torgler, Noblesse Oblige? Determinants of Survival in a Life and Death Situation, October 2008

2426 Giovanni Facchini, Peri Silva and Gerald Willmann, The Customs Union Issue: Why do we Observe so few of them?, October 2008

2427 Wido Geis, Silke Uebelmesser and Martin Werding, Why go to France or Germany, if you could as well go to the UK or the US? Selective Features of Immigration to four major OECD Countries, October 2008 
2428 Geeta Kingdon and Francis Teal, Teacher Unions, Teacher Pay and Student Performance in India: A Pupil Fixed Effects Approach, October 2008

2429 Andreas Haufler and Marco Runkel, Firms' Financial Choices and Thin Capitalization Rules under Corporate Tax Competition, October 2008

2430 Matz Dahlberg, Heléne Lundqvist and Eva Mörk, Intergovernmental Grants and Bureaucratic Power, October 2008

2431 Alfons J. Weichenrieder and Tina Klautke, Taxes and the Efficiency Costs of Capital Distortions, October 2008

2432 Andreas Knabe and Ronnie Schöb, Minimum Wage Incidence: The Case for Germany, October 2008

2433 Kurt R. Brekke and Odd Rune Straume, Pharmaceutical Patents: Incentives for R\&D or Marketing?, October 2008

2434 Scott Alan Carson, Geography, Insolation, and Institutional Change in $19^{\text {th }}$ Century African-American and White Stature in Southern States, October 2008

2435 Emilia Del Bono and Daniela Vuri, Job Mobility and the Gender Wage Gap in Italy, October 2008

2436 Marco Angrisani, Antonio Guarino, Steffen Huck and Nathan Larson, No-Trade in the Laboratory, October 2008

2437 Josse Delfgaauw and Robert Dur, Managerial Talent, Motivation, and Self-Selection into Public Management, October 2008

2438 Christian Bauer and Wolfgang Buchholz, How Changing Prudence and Risk Aversion Affect Optimal Saving, October 2008

2439 Erich Battistin, Clara Graziano and Bruno Parigi, Connections and Performance in Bankers' Turnover: Better Wed over the Mixen than over the Moor, October 2008

2440 Erkki Koskela and Panu Poutvaara, Flexible Outsourcing and the Impacts of Labour Taxation in European Welfare States, October 2008

2441 Marcelo Resende, Concentration and Market Size: Lower Bound Estimates for the Brazilian Industry, October 2008

2442 Giandomenico Piluso and Roberto Ricciuti, Fiscal Policy and the Banking System in Italy. Have Taxes, Public Spending and Banks been Procyclical in the Long-Run? October 2008

2443 Bruno S. Frey and Katja Rost, Do Rankings Reflect Research Quality?, October 2008

2444 Guglielmo Maria Caporale, Antoaneta Serguieva and Hao Wu, Financial Contagion: Evolutionary Optimisation of a Multinational Agent-Based Model, October 2008 
2445 Valentina Bosetti, Carlo Carraro and Massimo Tavoni, Delayed Participation of Developing Countries to Climate Agreements: Should Action in the EU and US be Postponed?, October 2008

2446 Alexander Kovalenkov and Xavier Vives, Competitive Rational Expectations Equilibria without Apology, November 2008

2447 Thiess Buettner and Fédéric Holm-Hadulla, Cities in Fiscal Equalization, November 2008

2448 Harry H. Kelejian and Ingmar R. Prucha, Specification and Estimation of Spatial Autoregressive Models with Autoregressive and Heteroskedastic Disturbances, November 2008

2449 Jan Bouckaert, Hans Degryse and Thomas Provoost, Enhancing Market Power by Reducing Switching Costs, November 2008

2450 Frank Heinemann, Escaping from a Combination of Liquidity Trap and Credit Crunch, November 2008

2451 Dan Anderberg, Optimal Policy and the Risk Properties of Human Capital Reconsidered, November 2008

2452 Christian Keuschnigg and Evelyn Ribi, Outsourcing, Unemployment and Welfare Policy, November 2008

2453 Bernd Theilen, Market Competition and Lower Tier Incentives, November 2008

2454 Ondřej Schneider, Voting in the European Union - Central Europe's Lost Voice, November 2008

2455 Oliver Lorz and Gerald Willmann, Enlargement versus Deepening: The Trade-off Facing Economic Unions, November 2008

2456 Alfons J. Weichenrieder and Helen Windischbauer, Thin-Capitalization Rules and Company Responses, Experience from German Legislation, November 2008 